\title{
Analysis of Code Transfer for Teachers and Students of Indonesian at the Robitul Istiqomah Huristak Islamic Boarding School
}

\author{
Eka Nur Estetis ${ }^{1}$, Sutikno, ${ }^{2, *}$, Syarifah Nelly Yohanna ${ }^{1}$, Evi Karlin ${ }^{1}$, Tri Aprilia \\ Anjani $^{1}$, Angga Andika Lubis ${ }^{1}$, and Yano Syafruddin ${ }^{1}$ \\ ${ }^{1}$ Postgraduate of Universitas Muslim Nusantara Al-Washliyah Medan, Indonesia \\ ${ }^{2}$ Lecturer of Universitas Muslim Nusantara Al-Washliyah Medan, Indonesia \\ *Corresponding author email: sutikno@umnaw.ac.id
}

\begin{abstract}
This research aimed at describe the form of code switching in Indonesian learning at the Robiitul Istiqomah Huristak Islamic Boarding School. The research method used is descriptive qualitative method. The data in this research was obtained from observations in the form of teacher and student speech. The result of the research is a form of code switching in Indonesian learning at the Robiitul Istiqomah Islamic Boarding School in the form of language translation. Language switching is in the form of code switching from Indonesian to Mandailing, code switching occurs from Mandailing to Indonesian.
\end{abstract}

Keywords: Code Switching, Mandailing, Learning

\section{INTRODUCTION}

The educational environment as a formal environment requires teachers and students to speak official languages in carrying out teaching and learning activities. Especially in Indonesian. This is as stated in the Law of the Republic of Indonesia Number 24 of 2009 Article 27 that Indonesian is the official language of the country and the language of unity. As the official language of the state, Indonesian functions as the official language of the state, as an introduction to education, national level communication, national cultural development, commercial transactions and communications, as well as a means of developing and utilizing science, technology, arts, and the language of the mass media. As a unified language, Indonesian functions as a national identity, national pride, a means of unifying various ethnic groups and nations, as well as a means of communication between regions and between regional cultures [1]-[2].

In carrying out learning, the language that is dominant in the school environment will greatly affect learning activities. If the teacher uses the mother tongue more often (regional language in everyday life to interact with fellow teachers and students. This is very likely there will be language selection, namely code mixing and code switching from Indonesian to regional languages. The background of the situation and these demands causes variations in the language varies because the members of the community who speak the language are diverse, and the language itself is used for various purposes [3]. In daily social interactions, speakers have unwittingly used language variations. Language selection is a symptom in aspects bilingual because in the repertoire there is more than one language. The material will also be easily conveyed if the teacher is aware of the use of Indonesian rules [4]-[5].

One of them is Pondok Pesantren Robitul Istiqomah (PPRI), the use of two or more languages to communicate in a school environment is very common. This is because the people of the region still predominantly use their mother tongue (local language). However, Indonesian teachers in the school environment always provide understanding and explanation to students to be able to use Indonesian in accordance with the rules in delivering material. However, there are still students who ask questions or otherwise use regional languages because they are used to using regional languages in communicating in their social environment. This causes code switching and code mixing in the teacher's speech either on purpose or spontaneously. Related to this, the criteria for using a good language is the accuracy in choosing a variety of languages according to communication needs. 
This research shows code switching and code-mixing affect teaching and learning activities in the classroom for students and teachers to understand each other. In this research, the researchers used sociolinguistic studies because it deals with code mixing and code switching. nor mix code. Sociolinguistics is a study of language associated with social conditions.

\section{LITERATURE REVIEW}

\subsection{Definition of Sociolinguistics}

The social function of language is a means of communication for interacting as well as a way of identifying a group of humans [6]. According to Iskandar et al. [7], language is a means of human communication in conveying messages between people.

According to Chaer [1], sociolinguistics is an interdisciplinary science between sociology and linguistics, two fields of empirical science that are very closely related. According to Santoso [8], opinion sociolinguistics is an interdisciplinary science which consists of the fields of sociology and linguistics, this discipline is a combination of sociology and linguistics so it is called linguistics plus societal.

\subsection{Code Transfer}

According to Suwito in Rosita [9], code switching is a transition event from one code to another. If the code transfer occurs between regional languages in one national language, or between dialects in a regional language or between several varieties and styles contained in one dialect, such code switching is called internal code switching. If what happens is a code shift between the original language and a foreign language, it is called an external code switching [10]-[12].

\subsection{Factors Causing Code Switching}

Code redirection is carried out consciously and with reason. The cause of code switching according to Fishman in Rosita [9] is who speaks, in what language, to whom, when and for what purpose. In various linguistic literature in general the causes of code switching are (1) speech or speakers, (2) listeners or interlocutors, (3) a change in situation with the presence of a third person, (4) a change from formal to informal or vice versa, (5) change of topic of conversation [13]-[15].

\subsection{Code Switching Functions}

Each code switching is always followed by a different function according to the factors that influence it [16]-[17]. Grosjean in Rosita [9] provides an overview of the function or purpose of code switching, namely (1) fulfilling linguistic needs, namely choosing the right words, phrases, sentences or discourse, (2) continuing the conversation according to the language used last, (3) quoting someone else's sentence, (4) mentioning the person intended in the conversation, (5) emphasizing the function of the conversation message, (6) emphasizing the involvement of the conversation, (7) marking and affirming group identity, (8) conveying secret matters, anger and irritation, (9) make the unwanted other person unable to understand the conversation, and (10) change the role of the conversation, raise status, assert authority, show intelligence.

\subsection{Bilingual}

Pranowo [18] reveals that Indonesian people are generally classified as bilingual. They master the first language (B1), that is regional language, and second language (B2), that is Indonesian. Agree with Hastuti [19], which states that someone who has the ability to use two languages interchangeably is called a bilingual.

\subsection{Learning Indonesian in the 2013 Curriculum}

Mahsum [20], Indonesian language learning contained in the 2013 curriculum with text-based learning aims to bring students according to their mental development, and solve real life problems by thinking critically. In its application, Indonesian learning has principles, namely as follows.

a. Language should be viewed as text, not merely a collection of words or linguistic rules.

b. The use of language is a process of selecting forms of language to express meaning.

c. Language is functional, meaning that the use of language can never be separated from the context, because the form of language used reflects the ideas, attitudes, values and ideology of the users.

d. Language is a means of forming human thinking.

\section{METHODOLOGY}

Research that focuses on code mixing and code switching in Indonesian learning at the Robitul Istiqomah Islamic Boarding School is a descriptive type of research. Descriptive research is research conducted by describing a situation objectively in a description of the situation. Descriptive research aims to provide a description of a particular symptom or community [21].

This research attempts to describe objectively the types of code mixing and code switching in Indonesian learning for the VII grade students of the Robitul Istiqomah Islamic Boarding School, as well as the factors causing code mixing and code switching in the incident. Data collection techniques in this research using the observation method. The researchers listen by following the Indonesian learning in class without participating in the conversation process. 
Table 1 The Form of Code Switching

\begin{tabular}{|c|c|c|}
\hline No & Interaction/Communication & Analysis \\
\hline 1 & $\begin{array}{l}\text { Teacher: Assallamuallaikum. Before starting the lesson } \\
\text { let us pray first. } \\
\text { Student: Yes, Miss. } \\
\text { Teacher: Before starting the lesson, I will attend you. } \\
\text { Teacher: Rina. } \\
\text { Student: Here, Miss. } \\
\text { Teacher: Mabia, how are you? } \\
\text { Student: Healthy, Miss. }\end{array}$ & $\begin{array}{l}\text { Code transfer from BI to BA contained in student speech as } \\
\text { in data (1) is in the form of the sentence "Olo, Ma'am." } \\
\text { which means "Yes, Miss." to show that students respond to } \\
\text { questions from the teacher about learning. In addition, the } \\
\text { teacher gives questions to students. In addition, the teacher } \\
\text { also intends to ask how they are doing, which is contained } \\
\text { in the sentence "Mabia, kabuyu?" equal to "Mabia, how are } \\
\text { you?" In the sentence described above, there have been } \\
\text { several times the transfer from Mandailing to Indonesian. }\end{array}$ \\
\hline 2 & $\begin{array}{l}\text { Teacher: Today our material is about short stories. } \\
\text { Have you ever heard the word short story? } \\
\text { Student: Yes, Miss. } \\
\text { Student: Ungada, I read short stories, Ma'am. The title } \\
\text { is Ana Hat. (Miss, I once read a short story titled Ana } \\
\text { Hat.) }\end{array}$ & $\begin{array}{l}\text { In that case the teacher opens learning about short stories } \\
\text { and asks students. The teacher explains in a professional } \\
\text { manner in Indonesian, as well as the students answer in } \\
\text { Indonesian. However, there were students who continued } \\
\text { using the Mandailing language that he had read short } \\
\text { stories. He tells the story or explains to the teacher using the } \\
\text { Mandailing language because he feels closer to speaking the } \\
\text { local language. }\end{array}$ \\
\hline 3 & $\begin{array}{l}\text { Teacher: Pade Madai, Mang. Madung is the progress } \\
\text { that some of you have read short stories. Maybe you } \\
\text { have read all the short stories without realizing it } \\
\text { Teacher: Sadarion, a manorangkon, the characteristics } \\
\text { of short stories. Well, open the book on page } 25 \text {. } \\
\text { Student: Yes, Miss. } \\
\text { Teacher: Ami read the meaning of short stories in } \\
\text { books. } \\
\text { Student: Yes, Miss. }\end{array}$ & $\begin{array}{l}\text { Furthermore, the teacher almost uses the Mandailing } \\
\text { language in teaching activities, this is indicated in the } \\
\text { sentence "Pade madai, Mang. Madung is progress." equal to } \\
\text { "That's good, Aon. You have progressed already." There, } \\
\text { the teacher did not always get carried away by using the } \\
\text { Mandailing language in explaining the material or simply } \\
\text { asking students. Likewise, students respond quickly using } \\
\text { the Mandailing language seen in the sentence "Olo, } \\
\text { Ma'am." equal to "Yes, Miss." In that case the teacher is } \\
\text { more dominant in using Code Switching. }\end{array}$ \\
\hline 4 & $\begin{array}{l}\text { Student: Miss, hurang mangarti au da bo Mother, do } \\
\text { you mean short stories on? } \\
\text { Teacher: Hurang mangarti ho ammang ndi dockon } \\
\text { book on. Ima short story is a carito nda pala ginjang } \\
\text { sampek marbab son novel chapter. } \\
\text { Student: Ooo, like that. } \\
\text { Teacher: Olo, adong dope nsu mangarti? }\end{array}$ & $\begin{array}{l}\text { In column } 4 \text {, sentences students are more daring to ask } \\
\text { questions using the Mandailing language because for them } \\
\text { it is easier to give understanding to the teacher about } \\
\text { something the students do not understand if using } \\
\text { Indonesian is contained in the sentence "Miss, hurang } \\
\text { mangarti au da bo, Mother, do you mean short stories on?" } \\
\text { equal to "Miss, I don't really understand the meaning of } \\
\text { short stories." The teacher also responds to the question } \\
\text { with the Mandailing language code transfer "Hurang } \\
\text { mangarti ho ammang ndi dockon book on. Ima short story is } \\
\text { a carito nda pala ginjang sampek marbab son novel } \\
\text { chapter." Short stories are stories that are not long and have } \\
\text { chapters like novels. }\end{array}$ \\
\hline
\end{tabular}




\section{RESULTS}

\subsection{Code Transfer Form}

The code switching contained in the speech of the Indonesian teacher at the Robitul Istiqomah Islamic Boarding School is in the form of language translation and variety transfer. Change of language code from BI (Indonesian) to BM (Mandailing Language).

\subsection{Transfer of BI Code (Indonesian) to BM (Mandailing Language)}

Based on the explanation of the table above, it can be said that every Indonesian teacher who teaches in seventh grade at the Robitul Istiqomah Islamic Boarding School uses the BM code in asking questions to get detailed information about students, to provoke new information, and to reaffirm the initial questions in another code.

\section{DISCUSSION}

The results of research on code switching in the Indonesian learning process at the Robitul Istiqomah Islamic Boarding School show that Indonesian subject teachers use more than one language during the learning process. Indonesian is used as the official medium of instruction and the Mandailing language is used to adapt to the situations and conditions that allow the language to be used.

Chaer [3] stated that the interlocutor or interlocutor can cause code switching, for example because the speaker wants to balance the language skills of the interlocutor, is not seen in the data analysis in this research. However, the results of the research prove that in learning Indonesian in schools where the majority of teachers and students are of Mandailing ethnicity, naturally code switching can take place between conversations during learning. It's just that sometimes the teacher doesn't really emphasize the use of the Mandailing language because they realize they have to speak Indonesian. In order for students to be skilled in speaking Indonesian, teachers use various strategies. One of them, by means of the teacher switching the BM code as an approach, invitation, or reaffirmation of the mastery of the material being studied by students.

When learning takes place, the teacher uses Indonesian as the main language in explaining the subject matter. Then when students are working on assignments in learning activities, students often ask questions in Mandailing, there are even students who express opinions in Mandailing. The teacher uses code switching into the Mandailing language when the students don't understand when the teacher explains the material in Indonesian. Students seem to show their understanding after being explained by the teacher in the Mandailing language. Mandailing language code switching is also used by the teacher as a form of emotional approach in
Indonesian as the language of instruction in every lesson, including learning Indonesian both in cities and villages. Even though the teacher responds to learning in class with local languages, the teacher is obliged to do the codeswitching back into Indonesian. From the results of preliminary observations, the researchers see that teachers at the Robitul Istiqomah Islamic Boarding School (PPRI) communicate more often in Mandailing both with fellow teachers and with students. The use of Mandailing is often encountered in teacher conversations with students when learning begins and when learning ends. The form of code switching into the Mandailing language that occurs in Indonesian learning at the Robitul Istiqomah Islamic Boarding School (PPRI) is as follows.

communicating with students because the majority of students speak Mandailing in daily life.

\section{CONCLUSION}

Based on the analysis of code switching in Indonesian learning at Negeri 3 Islamic Boarding School Robitul Istiqomah, it can be concluded that the form of code switching in Indonesian learning is in the form of language translation. Language switching is in the form of code switching from Indonesian to Mandailing, code switching occurs from Mandailing to Indonesian, meanwhile, code switching into Indonesian is carried out by the teacher to invite students to describe their knowledge into good Indonesian. The shift of code into the unofficial variety is intended by the teacher to make the learning atmosphere more relaxed or less rigid, especially during the last lesson. Meanwhile, code switching into the official variety is meant by the teacher to make students able to express their knowledge or final conclusions in correct Indonesian.

\section{REFERENCES}

[1] A. Haerun, Pembelajaran Bahasa Indonesia Dalam Konteks Multibudaya. Jurnal Al-Ta'dib, 9 (2) (2016), 74-91.

[2] K. Ummul. Pembelajaran Bahasa Indonesia dan Sastra (BASASTRA) di SD dan MI. AR-RIAYAH: Jurnal Pendidikan Dasar, 2 (1) (2018), 81-98.

[3] L. Chaer, Sosiolinguistik Perkenalan Awal. Jakarta: Rineka Cipta, 2010.

[4] S. Wahyuni, A. G. Samad, Bugis Language Interference with the Use of Indonesian Language in Communicating Students at SMP Negeri 1 Pammana. Journal of Indonesian Language Education and Literary, 4 (2) (2019), 10-15.

[5] H. Nataprawira, M. Carey, Towards Developing Colloquial Indonesian Language Pedagogy: A Corpus 
Analysis. Indonesian Journal of Applied Linguistics, 10

(2) (2020), 382-396.

[6] R. R. Simatupang, M. Rohmadi, K. Saddhono, Tuturan dalam Pembelajaran Bahasa Indonesia (Kajian Sosiolinguistik Alih Kode dan Campur Kode). Kajian Lingistik dan Sastra, 3 (2) (2018), 119-130.

[7] D. Iskandar, Mhd. Pujiono, I. A. Samad, The Profile of Acehnese Variation: Sociolinguistic Analysis. International Journal of Comparative Literature \& Translation Studies, 6 (3) (2018), 12-19.

[8] T. Santoso, Japanese and Javanese Directive Forms: A Study in Sociolinguistics. Culturalistics: Journal of Cultural, Literary, and Linguistic Studies, 2 (3) (2018), $17-24$.

[9] M. Rosita, Alih Kode dan Campur Kode Bahasa Jawa dalam Rapat Ibu-Ibu PKK di Kepatihan Kulon Surakarta: Kajian Sosiolinguistik. Skripsi. Jurusan Sastra Daerah, Universitas Sebelas Maret, Surakarta, 2011.

[10] D. Olson, The role of code-switching and language context in bilingual phonetic transfer. Journal of the International Phonetic Association, 46 (3) (2016), 263285 .

[11] F. A. Ansar, Code Switching and Code Mixing in Teaching-Learning Process. English Education: Jurnal Tadris Bahasa Inggris, 10 (1) (2017), 29-45.

[12] A. Alvanoudi, Language contact, borrowing and code switching. Journal of Greek Linguistics, 18 (1) (2018), 3-44.

[13] F. Albarillo, Information Code-Switching: A Study of Language Preferences in Academic Libraries. College \& Research Libraries, 79 (5) (2018), 624-644.

[14] R. R. Simatupang, M. Rohmadi, K. Saddhono, Alih Kode dan Campur Kode Tuturan di Lingkungan Pendidikan. LINGTERA, 5 (1) (2018), 1-9.

[15] B. T. Sundoro, S. Suwandi, B. Setiawan, Campur Kode Bahasa Jawa Banyumasan dalam Pembelajaran Bahasa Indonesia di Sekolah Menengah Kejuruan. RETORIKA: Jurnal Bahasa, Sastra, dan Pengajarannya, 11 (2) (2018), 129-139.

[16] Mardhiah. Analisis Alih Kode dan Campur Kode dalam Pembelajaran Bahasa Indonesia di SMP Negeri 3 Darul Hikmah Aceh Jaya. Tesis Magister. Pendidikan Bahasa dan Sastra Indonesia, Universitas Syiah Kuala, Aceh, 2020.
[17] K. A. Wedananta, Code-switching as a translanguaging to transfer cross-cultural understanding in English classroom: teachers' perception. International Journal of Linguistics, Literature and Culture, 6 (1) (2020), 70-78.

[18] Pranowo, Teori Belajar Bahasa. Yogyakarta: Pustaka Belajar, 2014.

[19] S. Hastuti, Sekitar Analisis Kesalahan Berbahasa Indonesia. Yogyakarta: Mitra Gama Widya, 2003.

[20] Mahsun, Teks Pembelajaran Bahasa Indonesia Kurikulum 2013. Jakarta: Raja Grafindo Persada, 2014.

[21] Sukandarrumidi, Metode Penelitian: Petunjuk Praktis Untuk Peneliti Pemula. Yogyakarta: Gadjah Mada University Press, 2006. 